ASIAN JOURNAL OF MANAGEMENT STUDIES

Journal homepage: https://www.sab.ac.lk/ajms/

Faculty of Management Studies Sabaragamuwa University of Sri Lanka

\title{
The Impact of Market Orientation on Organisational Performance: A Study of Small and Medium Scale Hotels in Tourism Industry in Southern Province, Sri Lanka
}

\section{TSLW Gunawardana ${ }^{1}$ and UKB Aravinda ${ }^{2}$}

${ }^{I}$ Faculty of Management and Finance, University of Ruhuna, Matara, Sri Lanka

${ }^{2}$ SDB Bank, Sri Lanka

\begin{abstract}
This research aimed to identify the impact of market orientation on organisational performance in small and medium scale tourist hotels in Southern province, Sri Lanka. This study used a structured questionnaire to collect data and partial least squares path modelling (PLS) to analyse the collected data. Hypothesis on interfunctional coordination and organisational performance was not statistically significant, whereas three hypotheses on customer orientation, competitor orientation, and social benefit orientation were statistically significant. All four hypotheses were indicated a positive impact on organisational performance. It thereby added to the existing body of literature and provided several insights for managers in the hotel industry and hospitality services. Since this field of inquiry is relatively new, it also offers numerous alternatives for further studies.
\end{abstract}

Keywords: Market Orientation, Organisational Performance, Partial Least Squares Path Modelling (PLS), Service Firms, Sri Lankan Tourism and SMEs
(C) Faculty of

Management Studies

Sabaragamuwa

University of Sri Lanka

ARTICLE INFO

Article history:

Received: 27 November 2020

Accepted: 09 January 2021

Published: 09 February 2021

E-mail Address:

gunawardana@badm.ruh.ac.lk

aravinda@sdb.lk 


\section{INTRODUCTION}

For nearly two decades, the market orientation has received extensive attention in both the academic and business world due to the critical role it plays in driving the success of a business (Brik et al., 2010; Masa'deh et al., 2018). Recent researchers (Wijesekara et al., 2016; Randhawa et al., 2020) argues that the market orientation perspective is predicated on the assumption that firms gain and sustain their competitive advantage by effectively serving dominant stakeholders and constantly meeting the changing needs of the market. New competitive challenges are continuously appearing and forcing firms to re-examine the market orientation perspective to improve their performance and sustain a competitive advantage (Almajali et al., 2016). There are several compelling themes relating to market orientation that have attracted attention in the literature, including the ability of the construct to prescribe useful "market-oriented" actions to managers (Harmsen \& Jensen, 2004), the reliance of market orientation on other constructs to strengthen its relationship with performance (Menguc \& Auh, 2006) and a lack of clarity about the nature of the construct (Gray \& Hooley, 2002). According to Kohli and Jaworski (1990), a firm exhibiting market orientation engages in the generation of market intelligence, disseminates this intelligence throughout the organisation - and develops effective strategies in response to this information. Business organisations should be vigilant to understand customer requirements because customers are very rational and knowledgeable. The prime activity of any organisation should be, therefore, satisfied the customers by fulfilling their requirements. Market orientation is defined as a form of the organisational culture where employees throughout the organisation are systematically and entirely committed to the continuous creation of superior customer value (Aldrich 1990; Herron \& Robinson 1993; Langerak et al., 2004). For that, business organisations should be developed various and different marketing strategies. As the philosophical foundation of market orientation (Jaworski \& Kholi 1993), the marketing concept serves as the primary justification for the clear role of customers in the planning and execution of market strategies. This research study examines the effects of market orientation on organisational performance in small and medium-scale tourism business organisations, specifically focus on the shape of Sri Lankan business industrial culture. 
In Sri Lanka, tourism is one of the largest foreign income earning industries. It is the third-largest export earner in the economy. Sri Lanka had witnessed unprecedented economic growth since the end of its three-decadelong civil conflict in May 2009. The tourism sector has emerged as a frontrunner in Sri Lanka's economic activities. According to World Travel and Tourism Council, the tourism industry contributed around 5.1 per cent to the country's gross domestic product (GDP) in 2017. Sri Lanka is on its way to becoming a major tourism destination in South Asia. Considering the high potential as a booming industry in Sri Lanka minor part of the industry (i.e. small and medium) is playing a major role but less evaluation and studies. Also, large-scale organisations have fixed strategies rooting bookings and international advertising campaigns with superior customer service. As the growing industry and sector in this study focus the small and medium scale tourist hotels in the Southern province, Sri Lanka.

Even though there are several researchers (Narver \& Slater, 1990; Nwokah, 2008; Foley \& Fahy, 2009) who have conducted researches on the impact of marketing orientation on organisational performance, they have selected only the market orientation and organisational performance only. Nevertheless, the review of literature conducted as part of this study confirms the existence of relatively few empirical studies focused on the performance consequences of market orientation for small and medium scale business (Aldrich, 1990; Herron \& Robinson, 1993). But in this study researcher has identified and developed a new conceptual research framework exploring the sub-variables, such as customer orientation, competitor orientation, interfunctional coordination, and social benefit orientation.

\section{LITERATURE REVIEW}

\section{Organisational Performance}

Organisational performance refers to the "firm's market and financial performance, which is positively related to the firm's economic value" (Slater \& Narver, 1994, p.58). According to the definition, three important concepts can be highlighted. Those are market performance, financial performance, and economic value. This study especially considers the market performance of the industry. Moreover, the literature argues that a market-oriented culture provides a unifying focus of organisational efforts in the delivery of value to customers while also providing a comparative impetus with competitors' 
activities (Kohli \& Jaworski, 1990). Therefore, a market-oriented firm is more likely to achieve high levels of customer satisfaction, to keep existing customers loyal, to attract new customers, and subsequently to attain the desired level of growth, market share, and hence of organisational performance (Homburg et al., 2000).

Moreover, organisational performance can be seen as a multidimensional construct consisting of more than simply financial performance (Baker \& Sinkula, 2005). According to scholars like Yamin and Harmelink (2001), Gunasekaran (1998), and Mavondo (1998), organisational performance refers to how well an organisation achieves it is market-oriented goals as well as its financial goals. Organisational performance is described as the extent to which the organisation can meet the needs of its stakeholders and its own survival needs (Griffin, 2003). Professional scholars, namely Stoelhorst and Richersson (2001) and Stolehorst and Van Raaij (2004), describe market orientation as marketing's explanation of performance differentials between firms. Although interest in organisational performance measurement is largely based on the assumption that greater marketing accountability enhances firm performance and marketing's stature (Rust et al., 2004), in the hotel industry, the concept of organisational performance is based on the idea that an organisation is the voluntary association of productive assets, including human, physical, and capital resources, to achieve a shared purpose (Pertusa-Ortega et al., 2010).

\section{Market Orientation}

Market orientation is by many scholars regarded as one of the most important concepts in the marketing discipline (Ruekert, 1992; Gainer \& Pandanyi, 2005; Carr \& Lopez, 2007; Wijesekara et al., 2016). However, it was not until the beginning of the 1990s that systematic research on market orientation, and the consequences of market orientation, really took off (Udriyah et al., 2019). Scholars argued that the postulate by Drucker (1954) that the customer must be the focus of an organisation's operations and the subsequent support given to this idea by Levitt (1960) that the customer is the reason for the organisation's existence were all pointing to the fact that market orientation behaviour was necessary at that time. According to Drucker (1954) and Levitt (1960), market orientation is a central element of management philosophy. This idea was extended to become known as the marketing concept (McNamara, 1972). The market orientation concept focuses on 
coordinated business intelligence generation, dissemination, and responsiveness to market information for efficient and effective decisions (Kohli \& Jaworski, 1990; Sundqvist et al., 2000). The concept is also concerned with issues including organisational culture, innovation, human resource planning, and organisational learning (Narver \& Slater, 1990; Ruekert, 1992; Baker \& Sinkula, 1999; Hooley et al., 2005; Keskin, 2006).

Market orientation can be defined as a form of an organisational culture where employees are committed to continuously create superior customer value or as a sequence of marketing activities that lead to better performance. Most of the researchers (Carr \& Lopez, 2007; Wijesekara et al., 2016) have concluded that high market-oriented companies perform better than less market-oriented companies. Moreover, market orientation has been widely accepted by scholars as to the implementation of the market concept, as organisational culture, or as a mix of those two (Greenley, 1995; Han et al., 1998). Other scholars argued that market-oriented behaviour in marketing new solutions leads to better performance, has positive effects on customer satisfaction and loyalty as well as innovation, employee satisfaction, and cooperation (Thwaites \& Lynch, 1992; Deshpandé et al., 1993; Gatignon \& Xuereb, 1997). In addition to that, there are many scholars (Baker \& Sinkula 2005; Keskin, 2006; Grinstein 2008) who tried to view market orientation in different ways. Although there are different concepts in marketing orientation, this study considers four concepts called customer orientation (Grinstein, 2008), competitor orientation (Narver \& Slater, 1990), inter-functional coordination (Shapiro, 1988), and social benefit orientation based on the perspectives of the most famous research scholars called Kohli and Jaworski (1990) and Slater and Narver (1990). Those are very important to get a sound understanding of the concept of market orientation and the progress of the research study.

\section{Customer Orientation}

The heart of the market orientation is its customer focus. To create superior value for buyers continuously requires that a seller understand a buyer's entire value chain, not only as it is today but also as it evolves (Day \& Wensley, 1988). Buyer value can be created at any point in the chain by making the buyer either more effective in its markets or more efficient in its operation (Slater \& Narver, 1990). Global competition increases market turbulence as well as the richness and diversity of knowledge possessed by 
customers and competitors (Achrol, 1991). Customer orientation can be defined as a group of actions taken by a business to support its sales and services staff in considering client needs and satisfaction as their major priorities (Slater \& Narver, 1990). Business strategies, therefore, that tend to reflect a customer orientation might be include developing a quality product appreciate by consumers, responding promptly and respectfully to consumer complaints and queries, and dealing sensitively with community issues.

To be customer-oriented implies that a firm is actively engaged in the organisation-wide generation, dissemination of, and responsiveness to, market intelligence (Kohli \& Jaworski, 1990). Usually, this term is described as an organisational culture that stresses the customer as the focal point of strategic planning and execution (Deshpande, 1999). This culture should be pervasive throughout the company such that employees consistently exhibit customeroriented behaviours, and consumers thereby become accustomed to this philosophy (Dobni et al., 2000). Customer orientation means that the attention of the R\&D and marketing departments is attuned to the voices of its customers (Griffin \& Hauser, 1993; Atuahene-Gima \& Evangelista, 2000). On the other hand, a firm's ability to cheaply and swiftly introduce new products that meet customer needs is the key to long-term success (Datar et al., 1997).

\section{Competitor Orientation}

According to Narver and Slater (1990), competitor orientation, as an element of market orientation, means that a seller understands the short-term strengths and weaknesses and long-term capabilities and strategies of both the current and potential competitors. According to Slater and Narver (1995), competitor orientation centres around the following questions, (1) where are the competitors? (2) what technologies do they offer? And (3) whether they represent an attractive alternative from the perspective of the target customers.

The purpose of a competitor orientation is to provide a solid basis of intelligence pertaining to the present and potential competitors for executive actions (Hsieh et al., 2008). Competitors are defined as firms offering products or services that are close substitutes, in the sense that they serve the same customer need (Porter, 1980; Kotler \& Amstrong, 2006). A firm's current and potential competitors may, therefore, be found among firms with similar and dissimilar production technology platforms (Harrison \& Shaw, 2004). A competitor orientation may lead to a cost advantage because competitor- 
oriented businesses tend to watch costs closely, so they may quickly match the marketing initiatives of competitors (Hsieh et al., 2008; Narver \& Slater, 1990).

Competitor orientation can enhance a firm's competitive advantage by allowing it to benchmark with, learn from, imitate, and improve on the products of successful competitors (Drew, 1997; Day \& Wensley, 1988). Unlike the long term benefits of customer orientation, empirical research has produced widely divergent findings on the relationship between competitor orientation and organisational performance. Narver and Slater (1990) and Noble et al. (2002) identified a positive relationship between competitor orientation and organisational performance. Harrison-Walker (2001) discovered that no such relationship exists between competitor orientation and organisational performance. Armstrong and Green (2007) and Armstrong and Collopy (1996) found the existence of a negative relationship between competitor orientation and organisational performance, and Luo et al. (2007) claimed that there is a curvilinear relationship between the two variables, competitor orientation and organisational performance. Armstrong and Collopy (1996) argued that competitor orientation reduced the profitability of a firm and suggested that firms should focus on maximising their profit and ignore their competitor's tactics completely.

\section{Inter-functional Coordination}

Inter-functional coordination (IFC) is defined as "the integration and collaboration of various functional areas (or departments) within an organisation as a way of enhancing communication and information to better meet the organisation's goal" (Narver \& Slater, 1990, p.22). According to Porter (1985), IFC can be defined as every department, facility, branch office, and other organisational units have a role that must be defined and understood. This is defined as the coordinated utilisation of organisational resources in creating superior customer value for the target segment. All employees, regardless of their distance from the strategy formulation process, must recognise their role in helping a firm achieve and sustainable competitive advantage. Inter functional coordination is defined in this study as the communication and sharing of information and resources and integration and collaboration of different functional areas or departments. 
As the literature on internal marketing is rapidly growing, IFC is also viewed as an important criterion of internal marketing. Rafiq and Ahmed (1993) defined the boundary between marketing and human resources management while arguing that organisations need to look at ways of increasing cross-functional coordination. Though mentioned as early as in 1993, IFC was not "officially" identified as one of the criteria of internal marketing until 1998, when Harris and Watkins (1998) proposed a comprehensive definition of internal marketing.

In another way, IFC is defined as the integration and collaboration of various functional areas (or departments) within an organisation as a way of enhancing communication and information to better meet the organisation's goal (Narver \& Slater, 1990). IFC describes the ability of different functional areas to accommodate disparate views and work around conflicting perspectives and mental models by putting aside functional interests for the better of the organisation as a whole. Nakata and Sivakumar (2001) highlighted that IFC represents a key form of internal social capital of an organisation. Organisational resources often have conflicting priorities, different perspectives, and strategies (Rafiq \& Ahmed, 1993). Academics and practitioners have long contended that synergy among company members is needed. A culture of integrating all departments towards better and continuous creation of customer value should lead to a market orientation within the company and the successful implementation of the marketing concept (Harrison \& Shaw, 2004).

\section{Social Benefit Orientation}

Social benefits can be defined as the increase in the welfare of a society that is derived from a particular course of action. Most social benefits cannot be quantified (Adler \& Kwon, 2002). Through this definition, it is crystal clear that social benefit orientation is attached to the welfare of the customers or the society, and every business organisation should pay high consideration to the social benefits. It comes with the concept of Corporate Social Responsibility. Furthermore, according to Adler and Kwon (2002), the social benefit is the total benefit to society from producing or consuming a good or service. Social benefits include all the private benefits plus any external benefits of production or consumption. Although in this definition, they highlighted that private benefit is a part of social benefit. This study concerns about the external benefits provided by the organisations. If a good or service has significant 
external benefits, then the social benefit will be greater than the private benefit (Carson, 1990). The social benefit achieved by a social project can be defined as the improvements attained in the living conditions of its beneficiaries that are directly attributable to the project.

Another way of explaining social benefit is defined by measurement against a "third-party standard," and all statutes permit incorporators to also pursue more "specific social benefits". Providing individuals or communities with beneficial products or services; Promoting economic opportunity for individuals or communities beyond the creation of jobs in the normal course of business, Preserving (or improving) the environment, Improving human health, promoting the arts, sciences, or advancement of knowledge; Increasing the flow of capital to entities with a public benefit purpose, or the accomplishment of any other particular, identifiable benefit for society or the environment (Doeringer, 2010). Based on the importance of the above perspectives, social benefit oriented activities has been increased. Most of the organisations are aimed to use strategies for positioning in consumer's mind about the organisations as well as the products. When it comes to the Sri Lankan context, because of the cultural situations, the social benefit has become a very important and essential concept today.

\section{Conceptual Framework and Hypotheses}

In this section, the approach is taken to develop an initial research model, and the hypotheses deduced from the research question and research objectives are described. Much care has been exercised to satisfy the criterion of replicability (Kerlinger, 1986). When developing the conceptual framework of the present study, based on the previous literature, measure the positive or negative impact on dependent variables by the independent variables (i.e., customer orientation, competitor orientation, inter-functional coordination, and social benefit orientation).

As mentioned, observational data collected prior to this study were important as they led to a research idea and hence provided some direction to the investigation. The literature reviewed in the previous section examined the theoretical and empirical work conducted into the benefits of being marketoriented in support of the view that such orientations lead to better organisational performance, as outlined in Figure 1. 


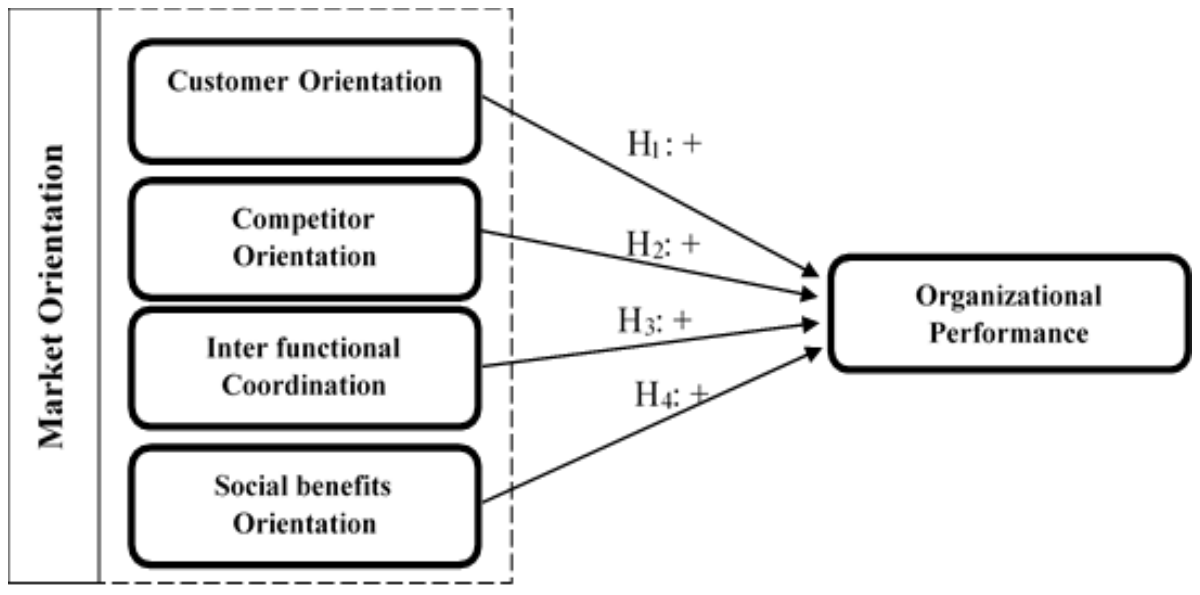

Figure 1: Conceptual Framework

\section{Customer Orientation and Organisational Performance}

The literature (Kara et al., 2005; Morgan et al. 2009) argues that a market-oriented culture provides a unifying focus of organisational efforts in the delivery of value to customers while also providing a comparative impetus with competitors' activities (Kohli \& Jaworski, 1990). Therefore, a marketoriented firm is more likely to achieve high levels of customer satisfaction; to keep existing customers loyal; to attract new customers; and subsequently to attain the desired level of growth, market share, and hence of organisational performance (Homburg \& Pflesser, 2000). According to Slater and Narver (1994), organisational performance refers to the firm's market and financial performance, which is positively related to the firm's customer orientation. Moreover, Deng and Dart (1994) conducted a research study by putting 148 firms across industries as their sample and could be able to find that there is a strong influence of customer-oriented activities on organisational performance. By considering the above previous research findings, the following hypothesis is proposed.

$\mathrm{H}_{1}$ : There is a positive influence of customer orientation on organisational performance.

\section{Competitor Orientation and Organisational Performance}

Complete reliance on customer orientation can often lead to incompleteness in business strategy, which leaves an organisation prone to a reactive posture in coping with competitor's strategies (Day \& Wensley, 1988). Further, they highlighted that competitor oriented strategies increase

Faculty of Management Studies, Sabaragamuwa University of Sri Lanka 
the performance of a firm. Griesinger and Livingston (1973) concluded from a review of experimental game literature that the proportion of "competitive" subjects varies depending on personality, cultural factors, and situational factors, such as feedback and game instructions. They also concluded that many subjects seemed eager to know what was expected of them so that they might adopt an appropriate orientation to the game. For example, the results from laboratory studies by Deutsch (1960) imply that explicit support for competitor-oriented objectives has a strong effect on organisational performance. In addition to that, in 1993, Slater and Narver has conducted a research and found that there is a positive association among subjective evaluation of organisational performance, sales growth, and new product success, relative to competitors and in 1996 also they have conducted a research, and they found that the competitor oriented activities positively association with sales growth, and firm performance and but not profit. Based on the above-mentioned research findings, the researcher supposes the hypothesis for the current study,

$\mathrm{H}_{2}$ : There is a positive influence of competitor orientation on organisational performance

\section{Inter-functional Coordination and Organisational Performance}

Several studies have linked IFC with organisational performance. Jaworski and Kohli (1993), using bank managers, investigated the relationship between IFC and organisational performance, putting market orientation in between. The results showed that IFC has a positive impact on market orientation, and market orientation is positively related to organisational performance. From the perspective of internal marketing, Caruana and Calleya (1998) collected data from marketing executives, examined the relationship between internal marketing and organisational performance. Farzad et al. (2008) studied the effect of the five criteria of internal marketing and market orientation on organisational performance in Iranian banks. According to Balakrishnan (1996), implemented research to find the relationship between market orientations and a firm's performance by putting IFC between them, and they found that IFC activities should be effectively managed on behalf of the success of the organisational performance. By considering the above research findings, the researcher proposed the following hypothesis, 
$\mathrm{H}_{3}$ : There is a positive influence of inter-functional coordination on organisational performance.

\section{Social Benefit Orientation and Organisational Performance}

The main thrust of benefit corporation statutes is to require these entities to pursue purposes beyond profit-making. Most social benefits cannot be quantified (Adler \& Kwon, 2002). Furthermore, the social benefit is the total benefit to society from producing or consuming a good or service. Social benefits include all the private benefits plus any external benefits of production or consumption. Although in this definition, they highlighted that private benefit is a part of social benefit, this study concerns about the external benefits provided by the organisations. If a good or service has significant external benefits, then the social benefit will be greater than the private benefit (Adler \& Kwon, 2002). Although the social benefit is very important to the organisation, so far, researchers do not consider social benefit orientation as a sub-component of the market orientation. Social benefit orientation is a new concept which specially adopted for this research study. There were no researchers who have been considered this concept related to market orientation. Therefore, there is some literature review to prove whether there is a positive relationship between social benefit orientation and organisational performance or not. With the concept of societal marketing, most businesses implement different kinds of socially beneficial activities such as donations, seminars, training programs, scholarships, and especially environmentfriendly activities. Through these kinds of strategies, organisations obtain a good reputation and make profitable relationships with customers. And also, it will enhance the quality of the organisation, and it will lead to long-term survival in the industry. By considering the current situation of the business industry, social benefit orientation helps to increase the performance of the organisation. Based on the above-mentioned situation, the researcher proposed the following hypothesis.

$\mathrm{H}_{4}$ : There is a positive influence of social benefit orientation on organisational performance 


\section{METHODOLOGY}

\section{Research Context}

The present study examines the impact of market orientation (i.e., customer orientation, competitor orientation, inter-functional coordination, and social benefit orientation) on organisational performance at small and medium-size hotels in Sri Lanka. Kerlinger (1986) describes research design as the structure of the research problem and the plan of investigation used to obtain empirical evidence on the relations of the problem. A single period of data collection through a single cross-sectional design is regarded as more adequate. The research strategy used in the current research involves, in line with the arguments outlined above, the use of a conclusive research design in the form of descriptive research.

Table 1: Description of Hotel Establishments

\begin{tabular}{lcc}
\hline Categorisation & Number of establishment & Number of rooms \\
\hline Classified tourist hotels & 138 & 13,079 \\
Five star & 22 & 4,950 \\
Four-star & 21 & 2,369 \\
Three-star & 23 & 2,364 \\
Two-star & 35 & 1,680 \\
One star & 37 & 1,716 \\
Unclassified/Tourist hotels & 229 & 9,756 \\
Boutique Hotels and villa & 68 & 830 \\
Guesthouse Stay/ Bungalows/ & 914 & 9,953 \\
Home Startments & 866 & 3,075 \\
Rented Homes and Apartme & & 36,393 \\
Total & 2,215 &
\end{tabular}

Source: SLTDA Statistical Report 2018 (q3) the data as of $30^{\text {th }}$ Sep. 2018

Chenhall (2003) defines context as environmental factors that may influence the research process and/or the instructional outcomes. This study focuses on small and medium scale hotels in the Tourism industry in Sri Lanka. In Sri Lanka, Tourism is the third-largest foreign income earning industry. After 30 years of war last five years' industry growth unprecedented more than $22 \%$ year on year, more than $80 \%$ to $90 \%$ were visitors coming here for holidays (SLTDA, 2018). According to World Travel \& Tourism Council, in 2017, international visitor arrivals recorded over 2.3 million, and the average revenue generated approximately US dollar 4713 million (World Travel \& Tourism Council, 2017). In 2018, lonely planet nominated Sri Lanka as the \#1 destination in the world to visit. In 2015, Forbes magazine ranked 
the island among the "top ten coolest countries" to visit. The government of Sri Lanka recognises the importance of developing tourism and the potential it has to create jobs (the tourism sector reportedly provided more than 875,000 total jobs in 2017) encourage domestic and foreign investment, and promote conservation practices (World Travel \& Tourism Council, 2017). Sri Lanka's exceptional island-wide natural and cultural endowments, the government of Sri Lanka, has positioned tourism as a central pillar of the economy. The government is determined to nurture world-class visitor experiences firmly rooted in the inherent natural, cultural, historical, and social capital of Sri Lanka and its people and to ensure that these experiences generate island-wide economic value for the industry. Accommodations are a key building block for any destination, and it is indicative that more than $95 \%$ of Sri Lanka's officially registered room stock is distributed around this popular route (SLTDA, 2018). The distribution of rooms according to star category is illustrated in Table 1.

\section{The Sample, Study Variables, Questionnaire Design and Data Collection}

The present study investigates the impact of market orientation on performance from the small and medium scale hotels in the Tourism industry in Southern province, Sri Lanka. The sampling frame was designed on the members' list of the Sri Lanka Tourist Board. The members' list offered useful information such as the name and addresses of small and medium Hotel owners, location, and telephone and fax numbers, while a simple random sampling method was applied to select the respondents from the population. The research conducts with $95 \%$ confidence. In conformity with this precedent, the level of analysis of the present study is the small and medium scale Hotels, while the unit of analysis is a Hotel owner as of the decisionmakers in small and medium scale hotels. The data collection had happened from December 2019 to February 2020. The respondent was small and medium scale tourist hoteliers in Southern province, Sri Lanka. Structural equation modelling (SEM) was used for data analysis. There are two statistical methodologies for estimating SEM with latent variables, the covariance-based (CBSEM) approach, and the variance-based partial least squares path modelling (PLS). CBSEM is the method of choice for theory testing, while PLS is appropriate for prediction oriented applications (Wold, 1982). Like any SEM, a PLS model consists of a structural part, which reflects the relationship between the latent variables, and a measurement component, which shows how the latent variables and their indicators are related (Haenlien \& Kaplan, 
2004). PLS is particularly appropriate when the model is complex because it does not lead to estimation problems or non-convergent results (Henseler et al., 2009). SEM does not only allow to analyse a set of latent factors like dependent and independent variables in regression analysis (Segars \& Grover, 1993) but also provides a comprehensive means to assess and modify theoretical models (Karahanna \& Straub, 1999). This study, therefore, uses PLS to tests the impact of market orientation on organisational performance based on predetermined hypotheses. Moreover, the achieved sample consists of 116 questioners. Out of 116 questionnaires, 110 were usable. Six questionnaires were unable to use. The overall response rate was $33.1 \%$. This study, therefore, uses PLS to process the data because of sample size is somewhat small. Demographic data analysis has done through the SSPS, and 96 respondents were males, and that was $87.3 \%, 14$ were females that was $12.7 \%$. The education level of the respondents was as follows, 53 respondents were passed the advanced level that was $48.2 \%$, 40 were graduates that was $36.4 \%$. Fifteen were having an only ordinary level that was $13.6 \%$. Two were the postgraduates that were $1.8 \%$. The questionnaire is composed of two parts. The first part of the questionnaire was designed to operationalise key variables under the market orientation, such as customer orientation, competitor orientation, inter-functional coordination, and social benefit orientation, and organisational performance. The second part of the questionnaire asks for demographic information about hoteliers. The five study constructs of the study i.e., organisational performance, customer orientation, competitor orientation, inter-functional coordination and social benefit orientation, and organisational performance, were operationalised as multi-item constructs. To measure organisational performance, ten items from Tanner's (2005) KEY OUTCOME scale were used. Customer orientation, competitor orientation, IFC, and social benefit orientation consisted of six, eight, seven, and seven items respectively, adapted from Narver and Slater (1990). The questions were developed by using a five-point scale ranging from " $1=$ strongly disagree" to " $5=$ strongly agree".

\section{RESULTS AND DISCUSSION}

The discriminant validity of the latent variables was tested using Fornell and Larcker (1981) approach. Table 2 shows the discriminant validity of each latent variable. The discriminant validity of the latent variables was tested using Fornell and Larcker's (1981) criterion, which requires that each latent variable's AVE is greater than the latent variable's squared correlation with

Faculty of Management Studies, Sabaragamuwa University of Sri Lanka 
any other construct in the model. The other entries in Table 2 show the square of correlations between constructs.

Table 2: Discriminant Validity of Constructs

\begin{tabular}{lccccc}
\hline \multicolumn{1}{c}{ Latent Variables } & 1 & 2 & 3 & 4 & 5 \\
\hline Customer orientation & 0.782 & & & & \\
Competitor orientation & 0.117 & $0 . .789$ & & & \\
Inter functional coordination & 0.361 & 0.168 & 0.777 & & \\
Social benefit orientation & 0.383 & 0.335 & 0.397 & 0.756 & \\
Organisational performance & 0.225 & 0.177 & 0.404 & 0.671 & 0.804 \\
\hline
\end{tabular}

Source: Survey Results 2020

\section{Impact of Market Orientation on Organisational Performance}

Table 3 shows the summary of the coefficient of determination $\left(\mathrm{R}^{2}\right)$. The study measures the coefficient of determination $\left(\mathrm{R}^{2}\right)$ of the endogenous latent variable, i.e. performance. The percentage of explained variance $\left(R^{2}\right)$ is 0.55 for performance. Besides, Table 3 summarises these relationships and shows the values of standardised path coefficients $(\beta)$, standard errors (se), tvalues $(t)$, and significance values $(p)$ of path coefficients, including model goodness of fit statistics.

Table 3: Results of PLS Path Model Estimation

\begin{tabular}{lc} 
& Performance $^{\mathrm{a}}$ \\
\cline { 2 - 2 } Path & Estimates (t-value) $^{\text {Market Orientation }}$ \\
Customer orientation & \\
Competitor orientation & $0.20\left(4.05^{* * *}\right)$ \\
Inter functional coordination & $0.21\left(2.80^{* *}\right)$ \\
Social benefit orientation & $0.06(0.73)$ \\
Model goodness-of-fit statistics & $0.56\left(8.93^{* * *}\right)$ \\
$X^{2}(d f)$ & $243.236(63)$ \\
SRMR & 0.126 \\
d ULS & 1.045 \\
d G & 0.365 \\
NFI & 0.142 \\
rms theta & 0.315 \\
Coefficient of determination $\left(\mathrm{R}^{2}\right)$ & 0.55 \\
\hline$* * * \mathrm{p}<0.001 ; * * \mathrm{p}<0.01 ; * \mathrm{p}<0.05$ & \\
apependent variable & \\
Source: Survey Results 2020 &
\end{tabular}

The results reveal that customer orientation has a positive and statistically significant relationship with organisational performance. This relationship is supported by data $(\beta=0.201, \mathrm{t}=4.048, \mathrm{p}<0.006)$ in harmony with postulated theory, results show that a firm's magnitude of customer

Faculty of Management Studies, Sabaragamuwa University of Sri Lanka 
orientation has a positive and statistically significant effect upon organisational performance. There is a positive and statistically positive relationship between competitor orientation and organisational performance $(\beta=0.212, t=2.801 ; p<0.000)$. There is a positive relationship between interfunctional coordination and organisational performance $(\beta=0.059, \mathrm{t}=0.734$; $\mathrm{p}<0.471)$. There is a positive relationship, but the relationship is not statistically significant. Social benefit orientation has a positive and statistically significant relationship with organisational performance. This finding is supported by the data $(\beta=0.564, \mathrm{t}=8.934 ; \mathrm{p}<0.000)$ and it is in expected direction.

Table 4: Confirmatory Factor Analysis of Constructs

\begin{tabular}{|c|c|c|}
\hline Constructs and indicators & $\begin{array}{l}\text { Standardise factor } \\
\text { loadings } \\
\text { (t-value) }\end{array}$ & $\begin{array}{l}\text { Composite } \\
\text { reliability/AVE }\end{array}$ \\
\hline \multicolumn{3}{|l|}{ Independent variable } \\
\hline Customer orientation & & $0.77 / 0.78$ \\
\hline \multicolumn{3}{|l|}{ Our Hotel gathers information about customers' needs } \\
\hline $\begin{array}{l}\text { Our Hotel has insight into the buying process of } \\
\text { customers }\end{array}$ & $0.80(4.480)$ & \\
\hline \multicolumn{3}{|l|}{ Competitor Orientation } \\
\hline $\begin{array}{l}\text { Our Hotel knows whether competitors are open to } \\
\text { complaints by customers. }\end{array}$ & & $0.76 / 0.79$ \\
\hline \multicolumn{3}{|l|}{ relationships with customers. } \\
\hline Inter-functional coordination & $0.78(5.851)$ & \\
\hline \multicolumn{2}{|l|}{$\begin{array}{l}\text { Our Hotel departments coordinate their contacts with } \\
\text { customers. }\end{array}$} & $0.75 / 0.78$ \\
\hline $\begin{array}{l}\text { Our Hotel departments are collectively responsible for } \\
\text { the relationship with customers. }\end{array}$ & $0.75(5.727)$ & \\
\hline Social benefit orientation & $0.80(6.123)$ & \\
\hline \multicolumn{2}{|l|}{$\begin{array}{l}\text { Our Hotel establishes policies by focusing on social } \\
\text { responsibilities. }\end{array}$} & $0.85 / 0.76$ \\
\hline $\begin{array}{l}\text { Our Hotel thinks social benefit as an obligation to } \\
\text { society. }\end{array}$ & $0.87(25.942)$ & \\
\hline \multicolumn{3}{|l|}{$\begin{array}{l}\text { Our Hotel think corporate social responsibility as an } \\
\text { obligation. }\end{array}$} \\
\hline Dependent variable & $0.80(14.174)$ & \\
\hline \multicolumn{2}{|l|}{ Organisational performance } & $0.72 / 0.80$ \\
\hline \multicolumn{3}{|l|}{ Has a highly competitive position } \\
\hline \multirow[t]{2}{*}{ Will change its existing services. } & $0.88(7.319)$ & \\
\hline & $0.60(15.483)$ & \\
\hline
\end{tabular}

Source: Survey Results 2020

Each construct in the measurement model was measured using multiple items. Each manifest variable in a certain measurement model is assumed to be generated as a linear function of its latent variables and the residual. Table 
4 presents an overview of the standardised factor loadings, t-values, composite reliabilities, and average variances extracted (AVEs). The analysis of the measurement model provides evidence of the robustness of the measures as indicated by their reliabilities.

The factor loadings of the latent variables are high and statistically significant. This confirms that the indicator variables and their respective underlying constructs are acceptable. The composite reliability values of the study constructs also reveal that the measurement model is reliable.

\section{CONCLUSION}

The study mainly examines the impact of market orientation on the organisational performance of small and medium scale hotels in the tourism industry in the Southern province, Sri Lanka. It is very important to consider market orientation by any organisation and how the market-oriented activities lead to the performance of the organisation because that is the most suitable way to achieve the goals and objectives of the organisations while earning fair profits and maintaining profitable relationships with customers. Even though there are several researchers (Herron \& Robinson, 1993; Keskin, 2006; Carr \& Lopez, 2007) who have conducted researches on the impact of marketing orientation on organisational performance, they have selected only the market orientation and organisational performance only. But in this study researcher has identified and developed a new conceptual framework including four subvariables (i.e., customer orientation, competitor orientation, inter-functional coordination, and social benefit orientation). The result of the present study is in line with the finding of Agrawal et al. (2003), which is "the market printed firm, through its market sensing and customer-linking capabilities, is likely to innovate, and that this, in turn, is likely to lead to the achievement of Superior performance" (Wijesekara et al., 2016, p. 49).

Even though the results of the present study show that customer orientation, competitor orientation, and social benefit orientation have a positive and statistically significant relationship with organisational performance, inter-functional coordination shows positive, but it is not a statistically significant relationship with organisational performance. Interfunctional coordination or integrated marketing means that all departments within the company play a critical role in achieving organisational performance. This idea is concurrent with Shapiro's (1988) research that found 
that market orientation is not a marketing orientation, because a market orientation does not suggest that only the marketing department has the most important role here. On the contrary, market orientation emphasises that all departments and all employees are aware of the fact that their job attitude towards internal and external customers is crucial. According to Narver and Slater (1994), competitor and customer orientation include all activities that involve generating market intelligence about customers and competitors, analysing it, and distributing that knowledge throughout the organisation. This means that the market-oriented company must provide adequate business processes and systems for data input and coordinate the communication of disseminated business info to create superior value for customers.

\section{Managerial Implications}

In any organisation, market orientation is a foundation to gain a competitive advantage, according to the literature. Managers now expect accurate delivery commitments, complete visibility into their orders and transactions, as well as proactive, personalised, and convenient support (Masa'deh et al., 2018). The results of the present study empirically tested that there is a strong positive impact from customer orientation, competitor orientation, inter-functional coordination, and social benefit orientation on organisational performance. And also, even inter-functional coordination shows the positive impact that it is not statistically significant. The hotel managers and owners, therefore, should be more focused on improving or enhancing inter-functional coordination. The findings of this study provide valuable information for the people who are managing the hotels to review their measure of customer values, customer satisfaction, and competitors' details, inter-functional coordination, and social benefit orientations. These findings provide details to the managers to focus on efficient service strategies to face a competitive advantage. These findings will provide information to employees to work together to achieve organisational performance.

Moreover, according to the study, the policymakers and the government can get the information to develop the industry guidelines and procedures to gain more income through the industry and service expansion. They can provide the institutional facilities/training to enhance the value-added to the customer service and to face a competitive advantage as the industry when compared with other countries. Policies should be industry-friendly as the tourism industry is vital to earn foreign revenues with country potential. 


\section{Future Research Directions}

There are some important limitations with findings, conclusions, and implications of this study. The study includes distorted views because of the study collects retrospective data, to some extent. Consequently, this study put on the perception-based variables. This study has been conducted only for the tourism industry to measure the impact of market orientation on organisational performance. Also, this study considers only small and medium scale tourist hotels. When selecting the sample, this study limited to the southern region, and a hundred and ten small and medium tourist hotels were selected as the respondents. The validity of generalisation to other types of businesses, such as manufacturing, is limited. And also, while conduct the study, consider only the quantitative factors. The effect of qualitative factors had not to capture in this study. Those are the limitations of this study. Future researchers can overcome those limitations, and especially they can use the qualitative factors in addition to the quantitative factors.

\section{REFERENCES}

Achrol, R. S. (1991). Evolution of the marketing organisation: new forms for turbulent environments. The Journal of Marketing, 77-93.

Adler, P. S., \& Kwon, S.W. (2002). Social Capital: Prospects for a New Concept. The Academy of Management Review, 27(1), 17-40.

Agrawal, S., Erramilli, M. K., \& Dev, C. S. (2003). Market orientation and performance in service firms: role of innovation. The Journal of Service Marketing, 17(1), 68-82.

Aldrich, H. (1990) Using an Ecological Perspective on Study Organisational Founding Rates. Entrepreneurship Theory and Practice, 14(3), 7-24.

Almajali, D. A., Masa'deh, R. E., \& Tarhini, A. (2016). Antecedents of ERP systems implementation success: a study on Jordanian healthcare sector. Journal of Enterprise Information Management, 29(4), 549-565.

Armstrong, J. S., \& Collopy, F. (1996). Competitor orientation: Effects of objectives and information on managerial decisions and profitability. Journal of marketing research, 188-199. 
Armstrong, J. S., \& Green, K. C. (2007). Competitor-oriented objectives: the myth of market share. International Journal of Business, 12, 117-136.

Atuahene-Gima, K., \& Evangelista, F. (2000). Cross-Functional Influence in New Product Development: An Exploratory Study of Marketing and R\&D Perspectives. Management Science, 46(10), 1269-1284.

Baker, W. E., \& Sinkula, J. M. (1999). The synergistic effect of market orientation and learning orientation on organisational performance. Journal of the academy of marketing science, 27(4), 411-427.

Baker, W. E., \& Sinkula, J. M. (2005). Market orientation and the new product paradox. Journal of Product Innovation Management, 22(6), 483-502.

Balakrishnan, K. (1996). Exponential distribution: theory, methods and applications. CRC press.

Brik, A.B., Rettab, B. and Mellahi, K. (2010). Market orientation, corporate social responsibility, and business performance. Journal of Business Ethics, 99(3), 307-324.

Carr, J. C., \& Lopez, T. B. (2007). Examining market orientation as both culture and conduct: modelling the relationships between market orientation and employee responses. Journal of Marketing Theory and Practice, 15(2), 113-125.

Carson, D. (1990). Some Exploratory Models for Assessing Small Firms' Marketing Performance (A Qualitative Approach). European Journal of Marketing, 24(11), 8-51.

Caruana, A. \& Calleya, P. (1998). The effect of internal marketing on organisational commitment among retail bank managers. International Journal of Bank Marketing, 16(3), 108-116.

Chenhall, R. H. (2003). Management control systems design within its organisational context: Findings from contingency-based research and directions for the future. Accounting, Organisations and Society, 28 (23), 127-168. 
Datar, S., Jordan, C., Kekre, S., Rajiv, S., \& Srinivasan, K. (1997). New product development structures and time-to-market. Management Science, 43(4), 452-464.

Day, G. S., \& Wensley, R. (1988). Assessing advantage: a framework for diagnosing competitive superiority. Journal of Marketing, 52(2), 1-20.

Deng, S., \& Dart, J. (1994). Measuring market orientation: a multi-factor, multi-item approach. Journal of marketing management, 10(8), 725-742.

Deshpande, R. (1999). Developing a market orientation. Thousand Oaks, CA: Sage.

Deshpandé, R., Farley, J. U., \& Webster, F. E. (1993). Corporate culture, customer orientation, and innovativeness in Japanese Firms: A Quadrant Analysis. Journal of Marketing, 57(1), 23-37.

Deutsch, M. (1960). The effect of motivational orientation upon Trust and suspicion. Human Relations, 13, 123-139.

Dobni, D., Ritchie, J. R. B., \& Zerbe, W. (2000). Organisational values: The inside of service productivity. Journal of Business Research, 47(2), 91107.

Doeringer, M. F. (2010). Fostering social enterprise: A historical and international analysis. Duke Journal of Comparative \& International Law, 20 (2), 291-330.

Drew, S. A. W. (1997). From Knowledge to Action: the impact of benchmarking on organisational performance. Long Range Planning, 30(3), 427-441.

Drucker, P. (1954). The principles of management. New York: Harper-Collins Publishers.

Farzad, A., Nahavandi, N., \& Caruana, A. (2008). The effect of internal marketing on organisational commitment in Iranian Banks. American Journal of Applied Sciences, 5(11).

Foley, A., \& Fahy, J. (2009). Seeing market orientation through a capabilities lens. European Journal of Marketing, 43(1/2), 13-20. 
Fornell, C., \& Larcker, D. F. (1981). Structural equation models with unobservable variables and measurement error: Algebra and statistics. Journal of marketing research, 382-388.

Gainer, B., \& Pandanyi, P. (2005). The relationship between market-oriented activities and market oriented culture: Implications for the development of market orientation in nonprofit organisations. Journal of Business Research, 58(6), 854-862.

Gatignon, H., \& Xuereb, J. M. (1997). Strategic orientation of the firm and new product performance. Journal of Marketing Research, 77-90.

Gray, B. J., \& Hooley, G. J. (2002). Guest editorial: market orientation and service firm performance - a research agenda. European Journal of Marketing, 36(9/10), 980-989.

Greenley, G. E. (1995). Market orientation and company performance: empirical evidence from UK companies. British Journal of Management, 6(1), 1-13.

Griesinger, D. W., \& Livingston Jr, J. W. (1973). Toward a model of interpersonal motivation in experimental games. Behavioural Science, 18(3), 173-188.

Griffin, A., \& Hauser, J. R. (1993). The voice of the customer. Marketing Science, 12(1), 1-27.

Griffin, K. (2003). Economic Globalization and Institutions of Global Governance. Development and Change, 34(5), 789-808.

Grinstein, A. (2008). The relationships between market orientation and alternative strategic orientations: A meta-analysis. European Journal of Marketing, 42(1/2), 115-134.

Gunasekaran, A. (1998). Agile manufacturing: enablers and an implementation framework. International Journal of Production Research, 36(5), 1223-1247.

Han, J. K., Kim, N., \& Srivastava, R. K. (1998). Market orientation and organisational performance: is innovation a missing link? The Journal of Marketing, 30-45. 
Harmsen H., \& Jensen B. (2004) Identifying the determinants of value creation in the market: A competence-based approach. Journal of Business Research, 57(5), 533-547.

Harris, L. C., \& Watkins, P. (1998). The impediments to developing a market orientation: an exploratory study of small UK hotels. International Journal of Contemporary Hospitality Management, 10(6), 221-226.

Harrison, P. J., \& Shaw, R. N. (2004). Intra-organisational marketing culture and market orientation: a case study of the implementation of the marketing concept in a public library. Library Management, 25 (8/9), 391398.

Harrison-Walker, L. (2001). The measurement of a market orientation and its impact on business performance. Journal of Quality Management, 6, 139172.

Henseler, J., Ringle, C. M., \& Sinkovics, R. R. (2009). The use of partial least squares path modelling in international marketing. In R. R. Sinkovics \& P. N. Ghauri (Eds.) New Challenges to International Marketing. Emerald Group Publishing Limited.

Herron, L. \& Robinson, R. B. (1993). A structural model of the effects of entrepreneurial characteristics on venture performance. Journal of Business Venturing, 8(3), 281-294.

Homburg, C., \& Pflesser, C. (2000). A multiple-layer model of marketoriented organisational culture: Measurement issues and performance outcomes. Journal of Marketing Research, 37(4), 449-462.

Homburg, C., Workman, J. P., \& Jensen, O. (2000). Fundamental changes in marketing organisation: The movement toward a customer-focused organisational structure. Journal of the Academy of Marketing Sciences, $28,459-478$.

Hooley, G. J., Greenley, G. E., Cadogan, J. W. \& Fahy, J. (2005). The performance impact of marketing resources. Journal of Business Research, 58(1), 18-27. 
Hsieh, Y. -C., Chiu, H. -C., \& Hsu, Y. -C. (2008). Supplier market orientation and accommodation of the customer in different relationship phases. Industrial Marketing Management, 37(4), 380-393.

Jaworski, B. J., \& Kohli, A. K. (1993). Market orientation: antecedents and consequences. The Journal of Marketing, 57(3), 53-70.

Kara, A., Spillan, J. E., \& DeShields, O. W. (2005). The effect of a market orientation on business performance: A study of small-sized service retailers using MARKOR scale. Journal of Small Business Management, 43(2), 105-118.

Karahanna, E., \& Straub, D. W. (1999). The psychological origins of perceived usefulness and ease-of-use. Information \& Management, 35(4), 237-250.

Kerlinger, F. N. (1986). Fundamentals of behavioural research. New York: Holt, Rinehart, Winston.

Keskin, H. (2006). Market orientation, learning orientation, and innovation capabilities in SMEs: An extended model. European Journal of Innovation Management, 9(4), 396-417.

Kohli, A. K., \& Jaworski, B. J. (1990). Market orientation: the construct, research propositions, and managerial implications. The Journal of Marketing, 54, 1-18.

Kotler, P., \& Amstrong, G. (2006). Principles of Marketing. New Jersey: Prentice-Hall.

Langerak, F., Hultink, E. J., \& Robben, H. S. (2004). The impact of market orientation, product advantage, and launch proficiency on new product performance and organisational performance. Journal of Product Innovation Management, 21(2), 79-94.

Levitt, T. (1960). Marketing Myopia. Boston.

Luo, X., Rindfleisch, A., \& Tse, D. K. (2007). Working with rivals: The impact of competitor alliances on financial performance. Journal of Marketing Research, 44 (1), 73-83. 
Masa'deh, R., Al-Henzab, J., Tarhini, A. Obeidat, B. Y. (2018). The associations among market orientation, technology orientation, entrepreneurial orientation and organisational performance. Benchmarking: An International Journal, 25(8), 317-342.

Mavondo, F. T. (1998). Market orientation: Re-conceptualizing dimensionality and implications for organisational performance. In B. J. Gray \& K. R. Deans (Eds.), Proceedings of the Australian \& New Zealand Marketing Academy Conference (ANZMAC) (pp. 1430-1450).

McNamara, C. P. (1972). The present status of the marketing concept. The Journal of Marketing, 50-57.

Menguc, B., \& Auh, S. (2006). Creating a firm-level dynamic capability through capitalising on market orientation and innovativeness. Journal of the Academy of Marketing Science, 34(1), 63-73.

Morgan, N. A., Vorhies, D. W., and Mason, C. H. (2009). Market orientation, marketing capabilities, and firm performance. Strategic Management Journal, 30(8), 909-920.

Nakata, C., \& Sivakumar, K. (2001). Instituting the marketing concept in a multinational setting: The role of national culture. Journal of the Academy of Marketing Science, 29(3), 255-276.

Narver, J. C., \& Slater, S. F. (1990). The effect of a market orientation on business profitability. The Journal of Marketing, 20-35.

Narver, J., \& Slater, S. (1994) Market orientation, customer value and superior performance. Business Horizons, 2, 22-28.

Noble, C. H., Sinha, R. K., \& Kumar, A. (2002). Market orientation and alternative strategic orientations: A longitudinal assessment of performance implications. Journal of Marketing, 66(4), 25-39.

Nwokah, G.N. (2008). Strategic market orientation and business performance: The study of food and beverages organisations in Nigeria. European Journal of Marketing, 42(3/4), 279-286. 
Pertusa-Ortega, E. M., Zaragoza-Sáez, P., \& Claver-Cortés, E. (2010). Can formalisation, complexity, and centralisation influence knowledge performance? Journal of Business Research, 63(3), 310-320.

Porter, M. E. (1980). Industry Structure and Competitive Strategy: Keys to Profitability. Financial Analysts Journal, 36(4), 30-41.

Porter, M.E. (1985). Technology and Competitive Advantage. The Journal of Business Strategy, 5(3), 60-68.

Rafiq, M., \& Ahmed, P. K. (1993). The scope of internal marketing: defining the boundary between marketing and human resource management. Journal of Marketing Management, 9(3), 219-232.

Randhawa, K., Wilden, R. and Gudergan, S. (2020) How to innovate toward an ambidextrous business model? The role of dynamic capabilities and market orientation. Journal of Business Research, 126(1). doi.org/10.1016/j.jbusres.2020.05.046

Ruekert, R. W. (1992). Developing a market orientation: an organisational strategy perspective. International Journal of Research in Marketing, 9(3), 225-245.

Rust, R. T., Ambler, T., Carpenter, G. S., Kumar, V., \& Srivastava, R. K. (2004). Measuring marketing productivity: Current knowledge and future directions. Journal of Marketing, 68(4), 76-89.

Segars, A. H., \& Grover, V. (1993). Re-examining perceived ease of use and usefulness: A confirmatory factor analysis. MIS Quarterly, 517-525.

Shapiro, B. P. (1988). What the hell is market-oriented? Harvard Business Review, 66, 119-126.

Slater, S. F., \& Narver, J. C. (1990). Market orientation, customer value, and superior performance. Business Horizons, 37(2), 22-29.

Slater, S. F., \& Narver, J. C. (1993). Product-market strategy and performance: an analysis of the Milesy Snow strategy types. European Journal of Marketing, 27(10), 33-51. 
Slater, S. F., \& Narver, J. C. (1994). Does competitive environment moderate the market orientation - performance relationship? Journal of Marketing, 58(1), 46-55.

Slater, S. F., \& Narver, J. C. (1995). Market orientation and the learning organisation. Journal of Marketing, 59(3), 63-74.

Slater, S. F., \& Narver, J. C. (1996). Competitive strategy in the marketfocused business. Journal of Market-Focused Management, 1(2), 159174

Sri Lanka Tourism Development Authority (SLTDA). (2018). Tourism Industry Report.

Stoelhorst, J. W., \& Richersson, P. J. (2001). A Naturalistic Theory of Economic Organisation. Journal of Economic Behaviour \& Organisation, 90, 545-556.

Stolehorst, J. W., \& Van Raaij, E. M. (2004). On explaining performance differentials: Marketing and managerial theory of the firm. Journal of Business Research, 57(5), 462-477.

Sundqvist, S., Puumalainen, K., Salminen, R. T., \& Cadogan, J. W. (2000). The interaction between market orientation, industry environment and business success: evidence from an exporting context. Australasian Marketing Journal, 8(1), 55-69.

Tanner, S. (2005). An investigation into how business excellence can contribute to sustained organisational performance in both private and public sector organisations. (DBA Dissertation). Henley Management College/Brunel University, UK.

Thwaites, D., \& Lynch, J. E. (1992). Adoption of the Marketing Concept by UK Building Societies. The Service Industries Journal, 12(4), 437-462.

Udriyah., Tham, J., \& Azam, S. M. F. (2019). The effects of market orientation and innovation on competitive advantage and business performance of textile SMEs. Management Science Letters, 9, 1419-1428. 
Wijesekara, W. A. D. S., Kumara, P. A. P. S., \& Gunawardana, T.S.L.W. (2016). Relationships between market and entrepreneurial orientation and organisational performance: Empirical evidence from small and medium scale garment manufacturers in Sri Lanka. Journal of Enterprising Culture, 24(1), 37-53.

Wold, H. O. A. (1982). Soft Modelling: The Basic Design and Some Extensions. In K. G. Joreskog \& H. O. A. Wold (Eds.), Systems under Indirect Observations: Part II. Amsterdam: North-Holland.

World Travel \& Tourism Council (2017). Economic Impact Reports. https://wttc.org/Research/Economic-Impact

Yamin, R. A., \& Harmelink, D. J. (2001). Comparison of linear scheduling model (LSM) and critical path method (CPM). Journal of Construction Engineering and Management, 127(5), 374-381. 